\title{
Risk Factors Causing Time Delay in the Jordanian Construction Sector
}

\author{
Zaydoun T. Abu Salem \\ Department of Civil Engineering \\ Applied Science Private University \\ Amman, Jordan.
}

ORcid \# 0000-0002-6880-5468

\author{
Akram Suleiman \\ Department of Civil and Infrastructure Engineering \\ Al-Zaytoonah University of Jordan \\ Amman, Jordan.
}

ORcid \# 0000-0002-2665-1384

\begin{abstract}
The construction sector in Jordan is an important economic area, contributing $3.1 \%$ to Jordan's GDP in 2016. The sector has changed over the past two decades since the end of gulf war; even changed rapidly in the last five years as a result of Arab spring, companies are encountered with more risks and uncertainties than before. One of major risks in the Jordanian construction industry is time delay, it is considered as inevitable. The goal of this study is to identify risk factors that cause time delay and then to explain the risk matrix for these factors in building projects in Jordan from the point of view of key construction project parties. The approach followed in the study is identifying main risk factors causing time delay. These factors are tabled in a questionnaire form and sent to construction professionals asking for their input in defining the risk framework of the 38 factors in terms of the effect and possibility of each hazard event. The framework was split into three categories (green, orange, and red) by the degree of severity over the time delay of the projects. Assessment of the 38 risk factors reveals that six elements of minor importance as they are in the green zone, 29 factors of medium importance in the yellow zone, and eight factors of critical importance in the red zone. This study's findings and suggestions will direct the project managers to improve their performance, which will have a significant impact on the sector.
\end{abstract}

Keywords: Risk management, Construction, Time delay, Matrix, Jordan.

\section{INTRODUCTION}

The construction sector is considered as one of the most important sectors in the Jordanian economy. According to Jordanian department of statistics, in 2016 the total number of registered contractors is 2977 , the total number of labors working in the construction sector is 36,160 , and the total number of construction projects is 2,844 with total cost equal 1,486 million JD. It therefore has a strong impact on Jordan's different economic, social and vocational sectors. The sector has changed over the past two decades since the end of gulf war; even changed rapidly in the last five years as a result of Arab spring, companies are encountered with more risks and uncertainties than before. One of major risks is time delay. Due to the time and cost overruns involved with construction projects, challenges in the Jordanian construction sector have been the focus of attention. Most projects are experiencing significant delays and thus exceeding official figures of time and cost. Enormous delays have a perfect environment for expensive lawsuits and claims in addition to conveying the economic possibility of capital projects. Several researches studied the Jordanian construction industry's key drivers of delay and identified many reasons. Most of these studies found that there are delays in each construction project and the severity of these delays varies significantly from project to another.

It is therefore important to recognize major risk factors that cause delays in time in order to implement risk management policies to alleviate these risks in the future by preventing, reducing or moving them. The main purposes of this study are to classify the risks that cause time delay in the construction sector in Jordan; then use the impact and likelihood of each risk to prepare the risk matrix and then categorize these risks according to their significance level. In reducing contract disputes, sensitivity to risk factors can aid developing industry practitioners.

\section{LITERATURE REVIEW}

Building projects around the world and in Jordan generally involve many risks, because things can easily go as expected, as a reason, risks in construction projects have become almost expected. Through everyday language and in numerous specialist fields, the word "danger" is used in many ways. The project risk definition given in the 2017 PMBOK is "an unpredictable occurrence or situation that has a encouraging or negative effect on the goals of a project if it evolves." Risks may impact at least one project constraint, such as time, price, range, or performance, on the target. Time risks are both threats to a project's progress and incentives. Threats tend to decrease the effectiveness of achieving the goals and incentives of the company. Project risk management includes the processes of scheduling, defining, evaluating, preparing for response and managing risk on a project. The objectives of project risk management are to improve the chances and effect of positive events and to reduce the likelihood and impact of negative outcomes of the project (PMBOK, 2013). Application of risk management begins with early planning in both budget cost analysis and initial scheduling to evaluate budgets and timelines with a reasonable level of trust in the target date and base price. 
For infrastructure and construction projects, time overruns or time delays are normal. The delay in time could be described as an event or disorder resulting in the project being completed well ahead than the contract stipulates. A delay may also be due to later than planned beginning or finishing a particular activity. Stumpf (2000) defined delay as an action or activity that enhances the time required by a contract to execute the tasks. It usually appears as additional working days or as a delayed operation launch. Several reports addressed the overrun of time and the key reasons of delay in regional and global construction projects. Assaf and Al-Hejji (2006) noticed that only $30 \%$ of Saudi Arabia's construction projects were executed within the projected achievement dates and the median overrun time was approximately $10 \%$ and $30 \%$. In large engineering projects, the survey highlighted 56 major causes of delay. The researchers divided the causes of the delay into nine major groups: finance, resources, contractual relationships, schedule adjustments, government relationships, personnel, planning and command, equipment, and environmental factors. Both parties selected the funding class of delay factors as the most important delay factor and selected the least significant environment group. Mahamid (2011) identified 43 reasons that could cause road construction project delays in Palestine. The study of these factors shows that there are eight variables in the risk matrix's red zone. Mezher et al. (1998) conducted an investigation into the reasons of delays in Lebanon's sector. It was found that stakeholders had more financial concerns; contractors saw contractual affairs as the most significant, although consultants saw project organization problems as the greatest reasons of delays.

Enshassi and Abu Mosa (2008) reported that owners in the Gaza Strip regarded awarding the project to unqualified architects as the most significant risk factor in the construction of houses, followed by faulty design and accident incidence due to poor safety procedures. Koushki et al. (2005) studied the effects of the causes of time overrun in construction projects in Kuwait. They asserted that the main causes of delay are the change of orders, the financial restraints of owners, and the lack of interest of owners. Faridi and El-Sayegh (2006) analyzed significant factors causing construction delays in the United Arab Emirates. The study has listed the top ten major causes of delays in construction.

Lo, Fung, and Tung (2006) research on the business of construction delays in civil engineering projects in Hong Kong was directed primarily to compile civil construction suppliers ' impressions of how significant the causes of delay are. Kaliba, Muya, and Mumba (2009) have researched the causes and effects of cost intensification and plan delays in highway construction contracts in Zambia. The researchers list the key drivers of delays in highways projects that are: overdue payments, financial processes and difficulties on the part of contractors and customers, contract adjustment, economic problems, sourcing of materials, changes in designs, personnel problems, unavailability of equipment, poor management, mistakes in design, weak on-site communication, and changes in specific areas. In another report, a study was conducted by Frimpong, Oluwoye, and Crawford (2003) to classify and evaluate the relative importance of reasons of delays and cost overruns in infrastructure construction projects in Ghana.
Studies showed that the main causes were monthly payment difficulties from governments, weak entrepreneurial leadership, product acquisition, poor technical quality, and material price escalation.

Odabaşi (2009) studied factors that influence the length of construction and the estimate of construction period models. The researcher selected from the publications and listed the most important ones under eleven headings as: expense, cash flow, on-site performance, material procurement, projectrelated factors, construction technology and methodology, experience, teamwork, environment, construction site, and the degree of build project completeness. The factors of construction delays are various, including storms, adverse weather, late owner decisions, and unexpected changes affecting building length, and so on, according to Hinze (1993). Mubarak (2005) groups the sources of construction delays into six classes irrespective of who is at fault; as follows: Differing Site Conditions, Design Issues or Omissions, Changes in Manager Requirements, Unusually Adverse Weather, Other Conditions and Force Majeure.

There are many research carried out in Jordan to determine the causes of delay in the construction projects in Jordan. Sweis et al. (2008) find that most journos accepted that the principal causes of construction delay are the money issues faced by the contractor and the owner's too many change orders. Some of the least significant factors are severe weather conditions and governmental policies rules and laws. Odeh and Battaineh (1999) found in a further study that the involvement of contractors and consultants was one of the top ten major causes of building delays in Jordan: inadequate contractor expertise, funding and paid income, productivity of labor; poor decision making, inappropriate scheduling and subcontractors.

In 130 public projects in Jordan, Al-Momani (1996) studied causes of delay. Designer, user modifications, environment, website conditions, poor customer service, economic conditions and quantity increase were the main causes of delay. Special attention to variables, the study indicated, would help business practitioners mitigate contract disputes. Battaineh (1999) considered the development reports of 164 buildings and 28 highway projects constructed in Jordan between 1996 and 1999. He observed significant delays: the actual percentage of real accomplishment time to the expected contract period is $160 \%$ for road construction projects and $120 \%$ for construction projects.

\section{RESEARCH METHODS}

From the existing literature, a number of 44 risk causes delays in construction projects have been identified. The variables were computed in a questionnaire form then the model questionnaire was examined with some local experts in order to evaluate its content to be relevant in the construction industry in Jordan. Of 44 factors, 38 factors have been identified and six factors have been excluded based on their recommendations and involvement in the construction sector in Jordan. The factors selected were divided into four groups: reasoning and environment, managerial, advisory and 
International Journal of Engineering Research and Technology. ISSN 0974-3154, Volume 13, Number 2 (2020), pp. $307-315$

(C) International Research Publication House. https://dx.doi.org/10.37624/IJERT/13.2.2020.307-315

financial. The targeted groups are the big contractors, consultants, and members of the construction companies.

Table 1. Scale used to identify risk Factor's impact and probability of occurrence.

\begin{tabular}{|c|c|c|c|l|}
\hline Scale & Impact/Severity & Probability of Occurrence & Risk Level & \multicolumn{1}{|c|}{ Meaning } \\
\hline$<20 \%$ & Very low & Very low & Level 1 & $\begin{array}{l}\text { The probability to occur is rare with very low } \\
\text { severity }\end{array}$ \\
\hline $20-40 \%$ & Low & Low & Level 2 & It is unlikely to happen with low severity \\
\hline $40-60 \%$ & Moderate & Moderate & Level 3 & Its occurrence is occasional with moderate severity \\
\hline $60-80 \%$ & High & High & Level 4 & It is likely to happen with high severity \\
\hline $80-100 \%$ & Very high & Very high & Level 5 & $\begin{array}{l}\text { Almost certain that the risk will occur with very high } \\
\text { severity }\end{array}$ \\
\hline
\end{tabular}

Table 1 displays the scale used to assess the effect and frequency of occurrence of each variable on time delay. The average response value for each variable is determined to assess its level of impact and its likelihood of occurrence. Figure 1 displays the risk matrix used to assess the risk zone for each defined variable (Green, Yellow, and Red). The matrix is 5X5 with an effect of very low (VL) to very high (VH) on the horizontal axis and the likelihood (with the same range) on the vertical axis.

Risks could be overlooked in the green zone, but risks in the yellow zone could be controlled and passed on if they occur. Nonetheless, if their risk of occurrence is low, it should be reduced and if their effect is high, it should be monitored and minimized and there should be contingency plans in place. Risks in the red zone must be treated as a priority and they should be given close attention.

Pilot tests were performed on specimens of prospective respondents in order to establish a fair validity of the results obtained and assess the accuracy of the questionnaire. The questionnaire was therefore circulated to 15 practitioners who were sincerely interested in providing objective evaluation and input on the instrument for collecting research data. In addition to minor comments related to contextual perceptions of a few questions, the input from the responders was generally positive. The questionnaire's internal reliability was checked by measuring the sets ' ' Cronbach's alpha.' The value of the alpha coefficient varies from 0 to 1 and is used to characterize the accuracy of variables derived from questionnaires on the dichotomous, multi-point formatted or ordinal rating scale. The stronger the score of the alpha constant, the more consistent the scale obtained. Nunnaly (1978) claimed that an appropriate coefficient of reliability is a value of 0.70 .

Cronbach's specimen alpha was calculated using the Social Sciences Statistical Package (SPSS V18) software, which collected a coefficient value of 0.841 , indicating an acceptable estimate of the reliability of the questionnaire by all participants. The questionnaire has been separated into two parts, the first part includes general questions about respondents, and the second part asks for their participation in defining the risk matrix in terms of impact and likelihood of occurrence for the delay factors found. Moreover, to engage in the study, a total of 144 randomly selected project managers were contacted. The questionnaire was sent asking for their ability to contribute in recognizing the risk matrix in terms of impact and likelihood of occurrence for the identified 38 risk factors. 116 were performed and submitted out of 144 questionnaires, making the response rate 80 percent.

\section{RESULTS AND DATA ANALYSIS}

\section{A. General characteristics of respondents}

Part 1 of the Questionnaire includes general questions about respondents as follows:

-Organization type

- Organization leadership position

- Organization expertise

- Building industry experience years.

Results show that $61 \%$ are owners, $25 \%$ are contractors, and $14 \%$ are tenants. The results of the position of the respondents were: $43 \%$ are project managers, $18 \%$ are site engineers, and $39 \%$ are design engineers. On the other hand, $30 \%$ of the specialization of the company of the respondents is construction, $42 \%$ is highway, and $28 \%$ are others. About $45 \%$ of respondents have more than 11 years of experience, $32 \%$ have 6-10 years of experience, and $23 \%$ have less than 5 years of experience. Finally, $44 \%$ of the organizations of the respondents have more than 11 years of experience, $31 \%$ have 6-10 years of experience, and $25 \%$ have less than 5 years of experience.

\section{RANKING OF RISK FACTORS}

The second section of the questionnaire consisted of an arithmetical metric scale ranging from one to five in an increasing order the level of influence of each risk factor surveyed. Risk factors have been ranked based on the 
percentage of possibility of occurrence and the percentage of hazard effects on project time. The findings in the four classes of the 38 variables as follows:

\section{A. Logic and environmental group}

Table 2 and Figure 2 show the hazard matrix and the rating of factors in the logic and environmental community; this group considers ten factors. The results show that there are two factors in the red zone, five factors in the yellow zone, and three factors in the green zone.

\section{B. Managerial group}

Table 3 and Figure 3 display the risk matrix and ranking of factors in the classification of managers, considering fifteen factors in this group. The results show that there is no factor in the red zone, there are ten factors in the yellow zone, and there are five factors in the green zone.

\section{Consultant group}

Table 4 and Figure 4 show the risk matrix and factor rating in the consultant group; seven factors are included in this category. The results suggest that there is no factor in the red zone under this band. The five factors are in the yellow zone, and there are two factors in the green zone under this band.

\section{Financial group}

The risk matrix and ranking of variables under the financial group are shown in Table 5 and figure 5.

\section{E. Top affecting factors}

Table 6 displays the major risk factors that cause delays in construction projects and their associated groups. Such variables are in the risk matrix region. From previous findings it can be seen that there are only four major risk factors, two are linked to the group of logic and environment, and the other two indicators are associated to the financial group. It is evident that the important factors are geotechnical and financially related, which means that these factors can be dominated and reduced by suitable geotechnical and site investigation and by governing the process of payment between project party groups.

\section{DISCUSSION}

This research established the risk matrix for factors causing delay in Jordan's construction projects. Research identified 38 risk factors distributed in the risk matrix based on the likelihood of occurrence and risk factor effects on the duration of the venture. There are four factors in the red zone, twentytwo factors in the yellow zone, twelve factors in the hazard matrix's green zone. The results showed that the most significant risk factors that severely affect the time of the project are falling in the red zone with high impact and high probability of occurrence, which means that these risks are occasional with high severity and need to be handled contiguously,

\section{Poor soil suitability \\ 2. Payments delay \\ 3. Poor ground condition \\ 4. Financial status of owner}

The first risk factor is poor soil adequacy with high impact and high chance of occurrence located in the red zone. Before beginning any related operation, the contractor will evaluate site circumstances that include geotechnical analysis. The three threats are also situated in the matrix's red zone, but with high impact and medium event likelihood. Payment delay could be avoided by regulating the payment process and accelerating issuance treatments and operations, particularly in government projects where many contractors suffer from government delay in paying their duties due to bureaucracy and lengthy paper processes.

Bad ground conditions in which ground conditions vary from what is predicted. It may lead in: a need to change the testable theory; a complete overhaul of the design, or the works may need to be completely abandoned. After the planning of the project schedule, the contractor must take into account all the possibilities because the effect of this hazard is high on the length of the project and the possibility of its existence is low. The owner's personal circumstances have a major impact on the venture, especially its length. If the owner is unable to pay the contractor's fees, the work will certainly be postponed as the contractor wants a consistent cash flow throughout the life of the project. To resolve this issue, before starting the project, the owner must guarantee the estimated cost of the project and the cash flows necessary for the project and provide the contractor with the essential payments.

\section{RECOMMENDATIONS}

The Jordanian government, the Jordanian Engineers Association (JEA) and the Jordanian Contractors Union (JCU) should recommend the following points in order to minimize and monitor risk factors that cause delays in Jordanian construction projects. Professional trainings should be carried out in collaboration with all project stakeholders to develop the managerial skills and skills of construction stakeholders. Legislations should be updated and strengthened to ensure that the architect and contractor carries out the appropriate site inspection, the requisite surveys and field investigations prior to the start of the design phase and the start of the construction phase.

Accredited science laboratories will concentrate on performing soil investigations. The contractor should access the site to ensure that it is ready to start working and to eliminate any problem with the site, especially the terrain. Contractors should recognize the lack of skilled labor on the Jordanian sector, there should be a sufficient number of labs available and assigned once the project is launched. 
Management and professional staff should be selected as soon as the project is awarded to all project stakeholders in order to avoid adjustments in management methods to arrange for finalization within a specified period. The operator, in particular the Jordanian authorities, shall not postpone payments due to the contractor, make progress payments to the contractor on time and ensure that cash flow is available on an ongoing basis as it enhances the capability of the contractor to fund the project.

Before assigning the contract, the owners will control their financial resources and capabilities. Contractor should also use progress fee to control his financial resources and schedule cash flow. Owner will review and approve project documents in collaboration with consultants prior to the construction process. Similar studies can be carried out in other Jordanian provinces / cities and for specific types of construction projects, such as infrastructure projects and highway construction projects, etc. Detailed studies can be carried out to analyze the impact of funding and cash flow issues on delays in construction projects.

\section{ACKNOWLEDGMENTS}

This work was supported in part by Al-Zaytoonah University of Jordan fund by the project titled "Risk factors causing delay of projects in the Jordanian construction sector", Resolution number 22/18/2018-2019.

\section{REFERENCES}

[1] Kerzner, H. (2017). Project management: a systems approach to planning, scheduling, and controlling. John Wiley \& Sons.

[2] Al-Momani, A. H. (1996). Construction cost prediction for public school buildings in Jordan. Construction Management \& Economics, 14(4), 311-317.

[3] Aibinu, A. A., \& Jagboro, G. O. (2002). The effects of construction delays on project delivery in Nigerian construction industry. International journal of project management, 20(8), 593-599.

[4] Assaf, S. A., \& Al-Hejji, S. (2006). Causes of delay in large construction projects. International journal of project management, 24(4), 349-357.

[5] Battaineh, H. (1999). Information system of progress evaluation of public projects in Jordan. Department of Civil Engineering, Jordan University of Science and Technology, Jordan.

[6] Enshassi, A., \& Abu Mosa, J. (2008). Risk management in building projects: owners' perspective. Risk management in building projects: Owners' perspective, 16(1).

[7] Faridi, A. S., \& El- Sayegh, S. M. (2006). Significant factors causing delay in the UAE construction industry. Construction Management and
Economics, 24(11), 1167-1176.

[8] Frimpong, Y., Oluwoye, J., \& Crawford, L. (2003). Causes of delay and cost overruns in construction of groundwater projects in a developing countries; Ghana as a case study. International Journal of project management, 21(5), 321-326.

[9] Hinze, J., Bren, D. C., \& Piepho, N. (1995). Experience modification rating as measure of safety performance. Journal of construction engineering and management, 121(4), 455-458.

[10] Kaliba, C., Muya, M., \& Mumba, K. (2009). Cost escalation and schedule delays in road construction projects in Zambia. International journal of project management, 27(5), 522-531.

[11] Koushki, P. A., Al- Rashid, K., \& Kartam, N. (2005). Delays and cost increases in the construction of private residential projects in Kuwait. Construction Management and Economics, 23(3), 285-294.

[12] Lo, T. Y., Fung, I. W., \& Tung, K. C. (2006). Construction delays in Hong Kong civil engineering projects. Journal of construction engineering and management, 132(6), 636-649.

[13] Mahamid, I. (2011). Risk matrix for factors affecting time delay in road construction projects: owners' perspective. Engineering, Construction and Architectural Management, 18(6), 609-617.

[14] Mezher, T. M., \& Tawil, W. (1998). Causes of delays in the construction industry in Lebanon. Engineering, construction and architectural management, 5(3), 252260.

[15] Mubarak, S. A. (2015). Construction project scheduling and control. John Wiley \& Sons.

[16] Nunnally, J. C. (1994). Psychometric theory 3E. Tata McGraw-Hill Education.

[17] Odabaşi, E. (2009). Models for estimating construction duration: An application for selected buildings on the Metu campus (Doctoral dissertation).

[18] Odeh, A. M., \& Battaineh, H. T. (2002). Causes of construction delay: traditional contracts. International journal of project management, 20(1), 67-73.

[19] Sambasivan, M., \& Soon, Y. W. (2007). Causes and effects of delays in Malaysian construction industry. International Journal of project management, 25(5), 517-526.

[20] Stumpf, G. R. (2000). Schedule delay analysis. Cost Engineering, 42(7), 32.

[21] Sweis, G., Sweis, R., Hammad, A. A., \& Shboul, A. (2008). Delays in construction projects: The case of Jordan. International Journal of Project Management, 26(6), 665-674. 
International Journal of Engineering Research and Technology. ISSN 0974-3154, Volume 13, Number 2 (2020), pp. 307-315

(C) International Research Publication House. https://dx.doi.org/10.37624/IJERT/13.2.2020.307-315

Table 2. Ranking of risk factors under logic and environment group

\begin{tabular}{|c|c|c|c|c|}
\hline Risk Factor & Probability & Impact & Matrix zone & Ranking \\
\hline Poor soil suitability & $\mathrm{H}$ & $\mathrm{H}$ & Red & 1 \\
\hline Poor ground condition & M & $\mathrm{H}$ & Red & 2 \\
\hline Insufficient labors & M & M & Yellow & 3 \\
\hline Poor terrain condition & M & M & Yellow & 4 \\
\hline Rework from poor material quality & $\mathrm{L}$ & M & Yellow & 5 \\
\hline Limited construction area & $\mathrm{L}$ & M & Yellow & 6 \\
\hline Rework from poor workmanship & $\mathrm{L}$ & M & Yellow & 7 \\
\hline High competition in bids & $\mathrm{L}$ & $\mathrm{L}$ & Green & 8 \\
\hline Unavailable construction materials & $\mathrm{L}$ & $\mathrm{L}$ & Green & 9 \\
\hline Disturbance to public activities & $\mathrm{L}$ & VL & Green & 10 \\
\hline
\end{tabular}

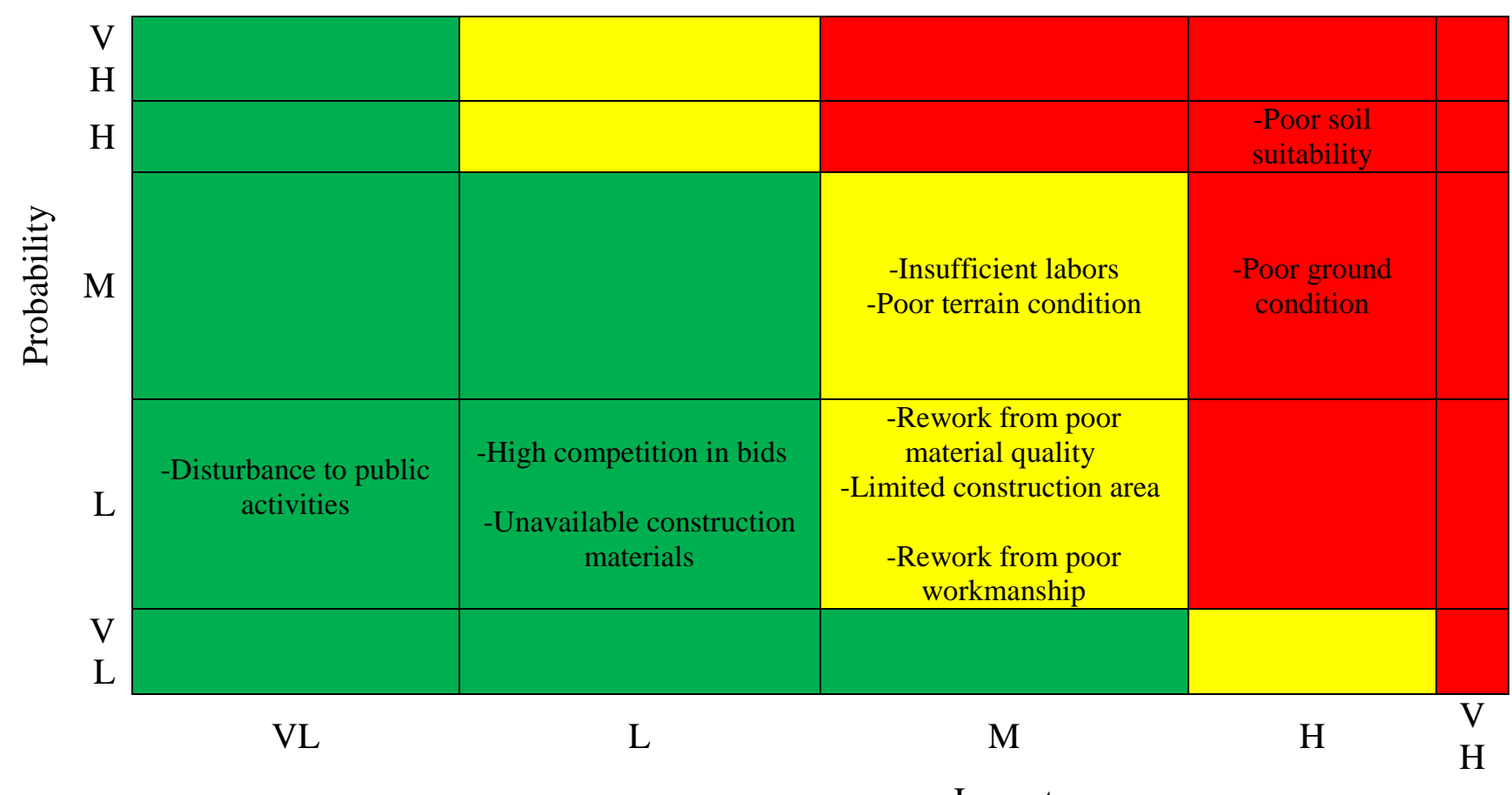

Figure 2. Risk matrix for factors under logic and environment group 
International Journal of Engineering Research and Technology. ISSN 0974-3154, Volume 13, Number 2 (2020), pp. $307-315$

(C) International Research Publication House. https://dx.doi.org/10.37624/IJERT/13.2.2020.307-315

Table 3. Risk matrix for factors under managerial group

\begin{tabular}{|c|c|c|c|c|}
\hline Risk Factor & Probability & Impact & Matrix zone & Ranking \\
\hline Delays in decision making & M & M & Yellow & 1 \\
\hline Design changes & M & M & Yellow & 2 \\
\hline Postponement of project & M & M & Yellow & 3 \\
\hline Late land hand-over & M & M & Yellow & 4 \\
\hline Changes in management ways & M & M & Yellow & 5 \\
\hline Unreasonable project time frame & $\mathrm{L}$ & M & Yellow & 6 \\
\hline Late issuing of approval documents & $\mathrm{L}$ & M & Yellow & 7 \\
\hline Late documentation & M & M & Yellow & 8 \\
\hline Internal administrative problems & $\mathrm{L}$ & M & Yellow & 9 \\
\hline Poor resource management & M & M & Yellow & 10 \\
\hline Delay in commencement & M & $\mathrm{L}$ & Green & 11 \\
\hline Improper construction method & $\mathrm{L}$ & $\mathrm{L}$ & Green & 12 \\
\hline Poor communication between construction parties & $\mathrm{L}$ & $\mathrm{L}$ & Green & 13 \\
\hline Undefined scope of working & $\mathrm{L}$ & $\mathrm{L}$ & Green & 14 \\
\hline Late submission of nominated materials & $\mathrm{L}$ & $\mathrm{L}$ & Green & 15 \\
\hline
\end{tabular}

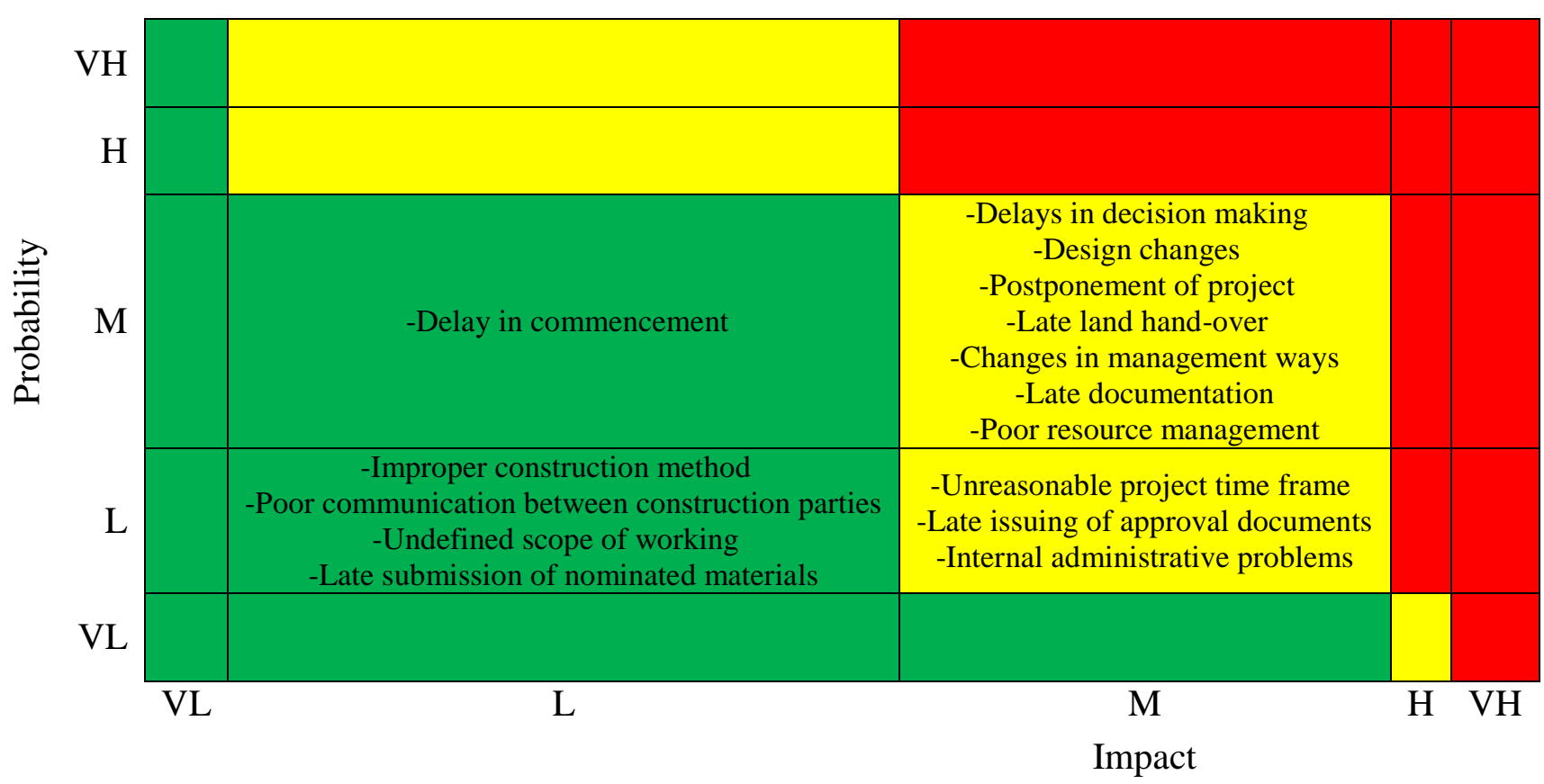

Figure 3. Risk matrix for factors under managerial group 
International Journal of Engineering Research and Technology. ISSN 0974-3154, Volume 13, Number 2 (2020), pp. $307-315$

(C) International Research Publication House. https://dx.doi.org/10.37624/IJERT/13.2.2020.307-315

Table 4. Risk matrix for factors under consultant group

\begin{tabular}{|c|c|c|c|c|}
\hline Risk Factor & Probability & Impact & Matrix zone & Ranking \\
\hline Late design works & M & M & Yellow & 1 \\
\hline Late approval & $\mathrm{L}$ & M & Yellow & 2 \\
\hline Inappropriate design & $\mathrm{L}$ & M & Yellow & 3 \\
\hline Late inspection & $\mathrm{L}$ & M & Yellow & 4 \\
\hline Mistake in design & $\mathrm{L}$ & M & Yellow & 5 \\
\hline Insufficient inspectors & $\mathrm{L}$ & $\mathrm{L}$ & Green & 6 \\
\hline Incapable inspectors & $\mathrm{L}$ & $\mathrm{L}$ & Green & 7 \\
\hline
\end{tabular}

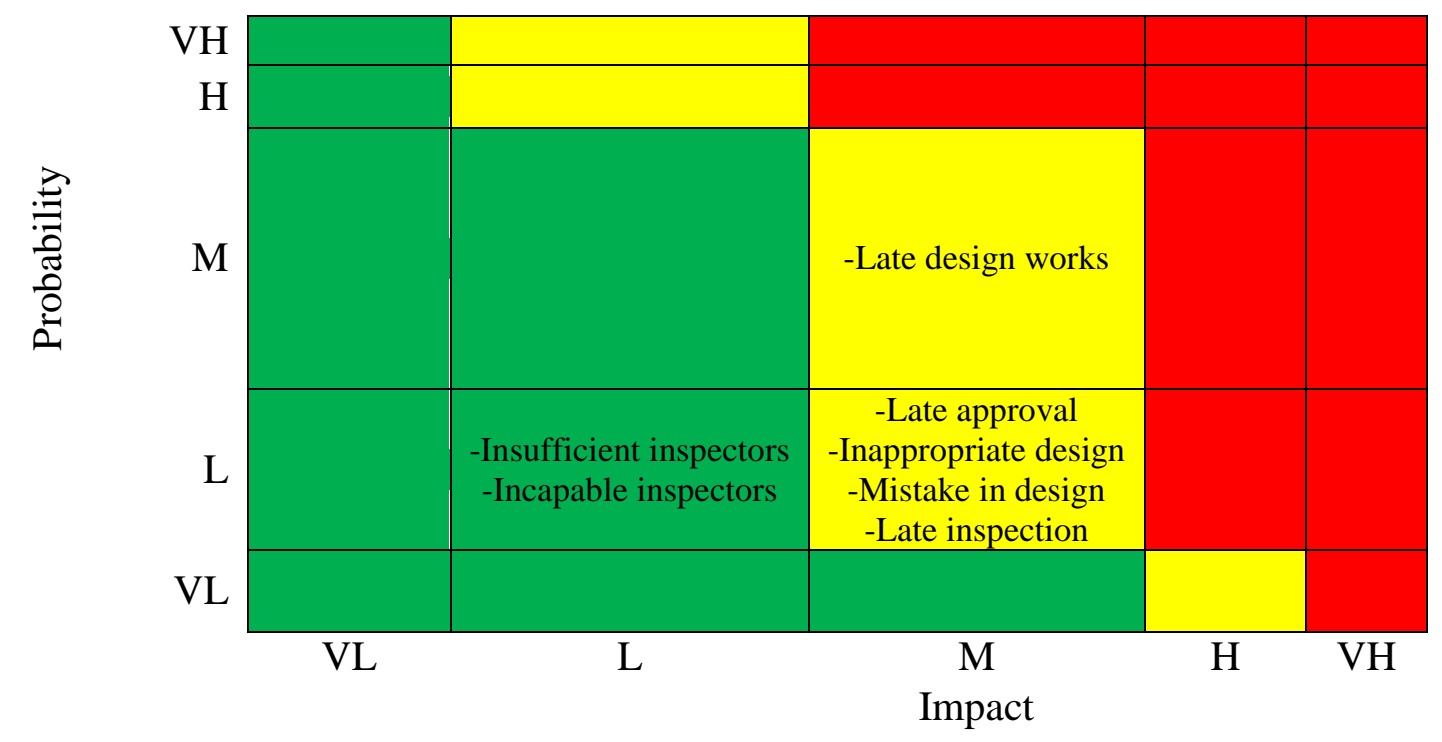

Figure 4. Risk matrix for factors under consultant group

Table 5. Risk matrix and ranking for factors under financial group

\begin{tabular}{|c|c|c|c|c|}
\hline Risk Factor & Probability & Impact & Matrix zone & Ranking \\
\hline Payments delay & M & H & Red & 1 \\
\hline Financial status of owner & M & H & Yellow & 3 \\
\hline Exchange rate fluctuation & M & M & Yellow & 4 \\
\hline Monopoly & L & L & Green & 5 \\
\hline Financial status of contractor & L & VL & Green & 6 \\
\hline
\end{tabular}


International Journal of Engineering Research and Technology. ISSN 0974-3154, Volume 13, Number 2 (2020), pp. $307-315$

(C) International Research Publication House. https://dx.doi.org/10.37624/IJERT/13.2.2020.307-315

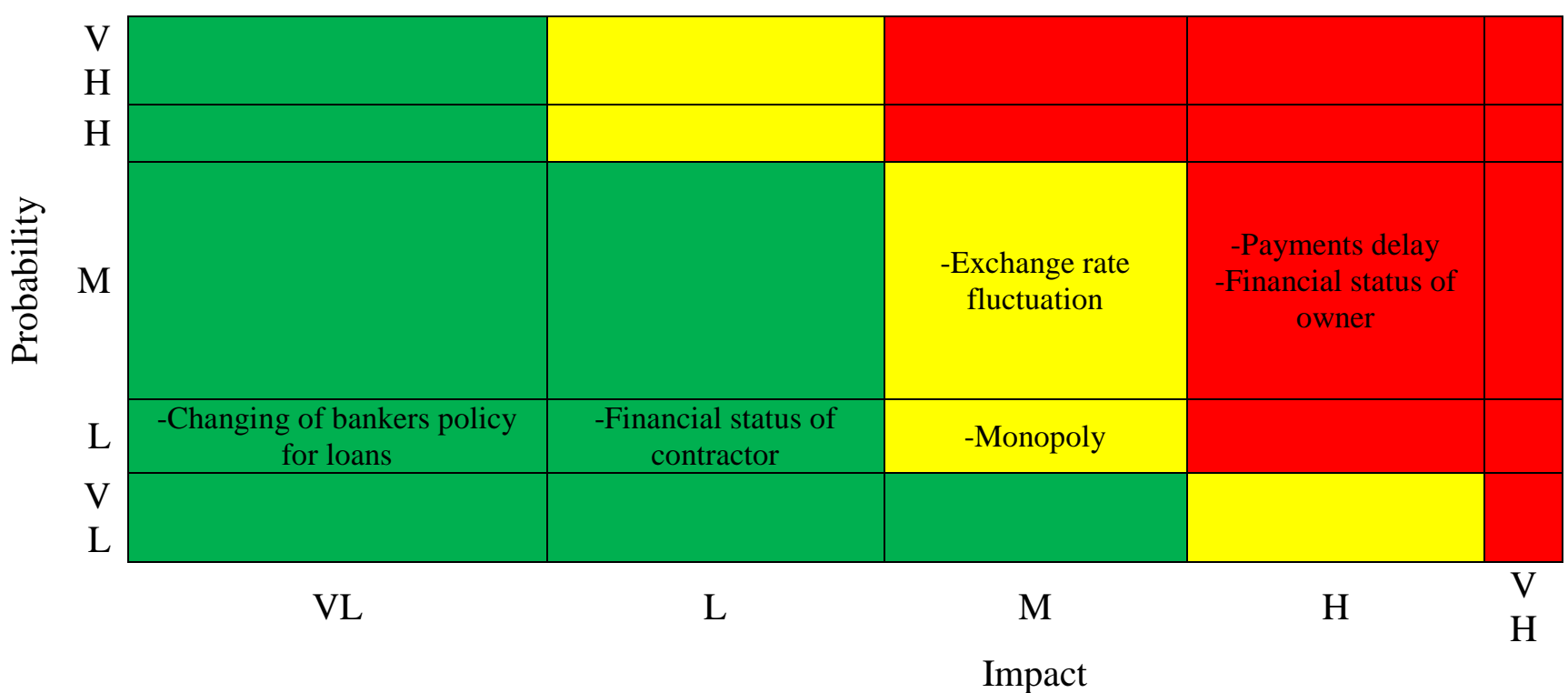

Figure 5. Risk matrix for factors under financial group

Table 6. Top significant risk factors and their related groups

\begin{tabular}{|c|c|c|c|c|c|}
\hline Risk Factor & Related group & Impact & Probability & Matrix zone & Ranking \\
\hline Poor soil suitability & Logic and environment & $\mathrm{H}$ & $\mathrm{H}$ & Red & 1 \\
\hline Payments delay & Financial & $\mathrm{H}$ & M & Red & 2 \\
\hline Poor ground condition & Logic and environment & $\mathrm{H}$ & M & Red & 3 \\
\hline Financial status of owner & Financial & $\mathrm{H}$ & M & Red & 4 \\
\hline
\end{tabular}

